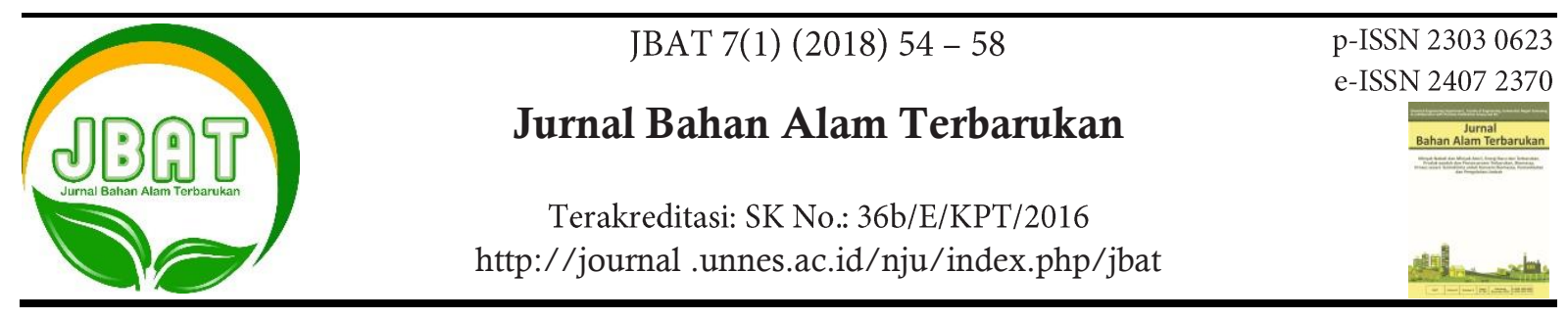

\title{
Comparison of Maceration and Ultrasonication Methods on Indigofera Tinctoria Linn Leaf Extraction
}

\author{
Nur Hidayati ${ }^{\bowtie}$, Tomy Kurniawan, Nindya I. Kusumawardani, Rahmah P. Sari
}

DOI 10.15294/jbat.v7i1.11405

Chemical Engineering Department, Faculty of Engineering, Universitas Muhammadiyah Surakarta, J1. A. Yani Tromol Pos 1 Pabelan, Kartasura, Surakarta, Indonesia, 57102

\begin{tabular}{l} 
Article Info \\
\hline Article history: \\
Received \\
October 2017 \\
Accepted \\
December 2017 \\
Published \\
June 2018 \\
\hline Keywords : \\
Indigo; \\
Indigofera Tinctoria \\
Linn; \\
Natural Dyes; \\
Maceration; \\
Ultrasonication
\end{tabular}

\begin{abstract}
The extraction of Indigofera Tinctoria Linn leaf into natural dyes was studied using two methods: maceration and ultrasonication. Other variables tested were the differences in the degree of solvent acidity used: neutral, alcoholic, acid and base. The yield and the dye strength measured by the absorbance are response to the change of those variables. The better yields were obtained from ultrasonication method compared to the maceration one. The highest yield was shown in the result of maceration method at neutral condition, $2.3 \%$, while in ultrasonic method was at alcoholic condition $13 \%$. The acidity of the solvent affects the resulted colour. By using maceration method and the neutral condition produced dark blue, the acid solvent produced a grey dye, the alkaline produced a greenish dye and the alcoholic produced a brownish dye. With the aid of ultrasonication, blue dye was generated on the use of neutral, acid and alcoholic solvents, whereas brownish was on alkaline solution.
\end{abstract}

*This is a revised and extended version of an article which had been presented at SNTK UNNES 2017, Semarang, Indonesia, September 20 2017.

\section{INTRODUCTION}

Colouring textile using synthetic dyes have a high negative impact towards both environment and human beings that are involved in the manufacturing process to the user. The increased awareness of environmental and health hazards associated with synthesis, processing and use of synthetic dyes has created an interest in naturally dyed textiles (Mongkholrattanasit et al. 2010). This is encouraged because natural sources of dyes such as from plants, insects, minerals and fungi are in abundance.

Natural dyes for textile materials are mostly obtained from the extraction of various parts of plants such as roots, wood, leaves, seeds or flowers (Maulana \& Handayani 2013). Some natural dyes does not only colour with unique and elegant colours, but also possess antibacterial, odour removing and protection from ultraviolet (UV) ray functions for fabrics (Punrattanasin et al. 2013).

Various efforts are still being made to address the various deficiencies of natural dyes due to reproducibility uncertainty and lack of fade-proof properties. This study deals with the extraction of dyes from Indigofera Tinctoria Linn to investigate the different methods of extraction and solvents used.

Indigofera is a native plant of East and Southern Africa that has been introduced to Laos, Vietnam, Philippines and Indonesia (Sumatera, Java, Sumba and Flores) (Mualimin 2013). Indigo

(C) 2018 Semarang State University

\footnotetext{
${ }^{\square}$ Corresponding author:

Chemical Engineering Department, Faculty of Engineering,

Universitas Muhammadiyah Surakarta, Kartasura, Surakarta, Indonesia, 57102

E-mail: nur.hidayati@ums.ac.id
}

ISSN 2303-0623 
Table 1. Yield and colour of extraction results

\begin{tabular}{ccccc}
\hline \multirow{2}{*}{ Solution } & \multicolumn{3}{c}{ Method } \\
\cline { 2 - 5 } Condition & Yield (\%) & Colour & Yield (\%) & Ultrasonication \\
\cline { 2 - 5 } & 2.39 & Dark Blue & 2.07 & Dark Blue \\
Neutral & 1.25 & Grey & 5.60 & Blue \\
Acidic & 1.03 & Greenish & 2.46 & Brownish \\
Alkaline & 1.59 & Brownish & 13.08 & Dark Blue \\
Alcoholic & &
\end{tabular}

is formed from the indican by fermentation of several types of substances present in plants such as Baphicacanthus cusia Brem, Indigofera Suffruticosa, Polygonum Tinctorium, Isatis Indigotica and Couropita Guianensis followed by air oxidation from indoxyl (Tayade \& Adivarekar 2014; Chanayath et al. 2002). On the process of dyeing textiles with natural dyes, indigo is considered as the most important natural blue dye (CI Vat Blue I), Woad (Isatic tinctoria L.), and Dyer's Kntweed (Polygonum tinctorium Ait.) (Bechtold et al. 2002).

Natural dyes from different origins can be extracted using aqueous method which uses water for extraction with or without the addition of salt/acid/alkaline/alcohol in the extraction bath. This study researched the method of dye extraction from Indigofera Tinctoria Linn plant using water under acidic, alkaline, alcoholic and neutral conditions done conventionally as well as with the help of ultrasonic wave.

\section{RESEARCH METHODOLOGY}

The Indigofera Tinctoria Linn plant, which is around 1-2 months old used in this research, is partly obtained from farmers in Temanggung and Edupark of Universitas Muhammadiyah Surakarta. Solvents based on acidic conditions is prepared by adding $\mathrm{H}_{2} \mathrm{SO}_{4} 1 \% \mathrm{v} / \mathrm{v}$, whereas alkaline condition is done by adding $\mathrm{NaOH} 1 \% \mathrm{~b} / \mathrm{v}$, alkoholic condition is prepared by adding technical ethanol so that the solution concentration is $50 \% \mathrm{v} / \mathrm{v}$, while the neutral condition is prepared by using only distilled water.

The dye extraction is carried out as follows. A number of leaves, twigs and solvents (neutral, acid, alkaline, and alcoholic) are mixed with a ratio of $1: 8$. The mixture is then immersed in either a regular tub for 24 hours or in an ultrasonic bath for 4 hours. Then for both methods, the residues are separated from the liquid. Ambient air is passed into the liquid by means of a pump through a $0.5 \mathrm{~cm}$ diameter hose pipe in order for an oxidation reaction to occur and to precipitate the resulting dye particles, which are added to a $40 \mathrm{~mL}$ lime solution per $1000 \mathrm{~mL}$ of filtrate that is prepared by dissolving 1 gram of $\mathrm{CaCO}_{3}$ in $25 \mathrm{~mL}$ of distilled water. The liquid is then left for \pm 12 hours, and separated between the liquid and the resulting precipitate. The precipitate is dried by aerating without direct sunlight until dry powder is obtained. The powder is then stored in a dry container avoiding direct sun exposure for further tests. The yield is determined by the mass of the dye obtained from the drying result divided by the mass of the leaves and twigs of the processed raw material.

The strength of the natural indigo-blue dye is measured by a spectrophotometer (Spectonic Genesys 20 UV-Visible) at a wavelength of $440 \mathrm{~nm}$ and compared with synthetic indigo dye, indigosol. Understanding the functional groups contained in the dye is carried out by using FTIR test.

\section{RESULTS AND DISCUSSION}

In the twigs and leaves of fresh Indigofera tinctoria, indican belonging to the indigoida matter are present, which is soluble in water due to the influence of indimulase enzyme that turned into indoxyl and sugar. In an alkaline condition, this indoxyl is easily oxidized by air, turning into a blue, indigo pigment (Chanayath et al. 2002). Table 1 shows the yield and color produced under various solvent conditions. The method of processing and the solvent conditions used affected the yield and the resulting color.

In the maceration method, the highest yield, 2.39\%, was obtained in a neutral solution, whereas with the aid of ultrasonication yielded $13.08 \%$ in alcoholic solution. The amount of yield is strongly influenced by the quality and time of raw material storage (Bechtold et al. 2002) and the process used. The quality of the raw material determines the amount of the content of the indican. Extended storage time at ambient temperature also reduces the yield. To reduce the effect of raw material storage time on yield, the raw 


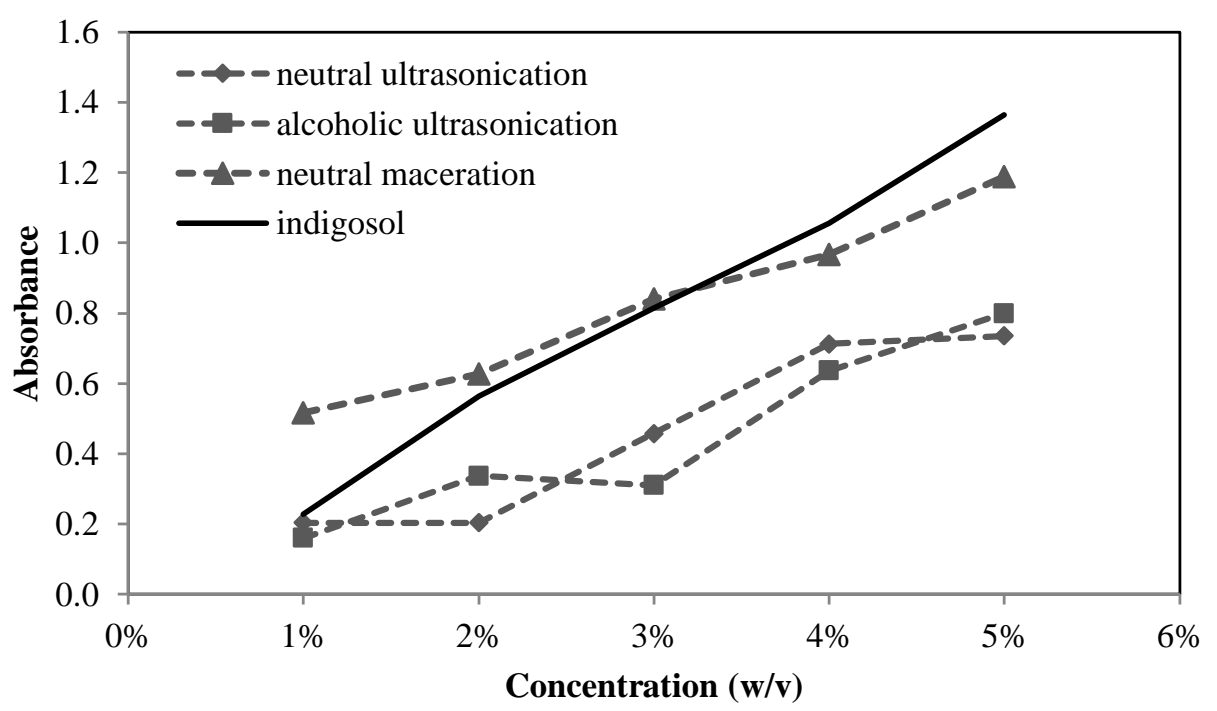

Figure 1. Absorbance of indigo natural dyes and indigosol

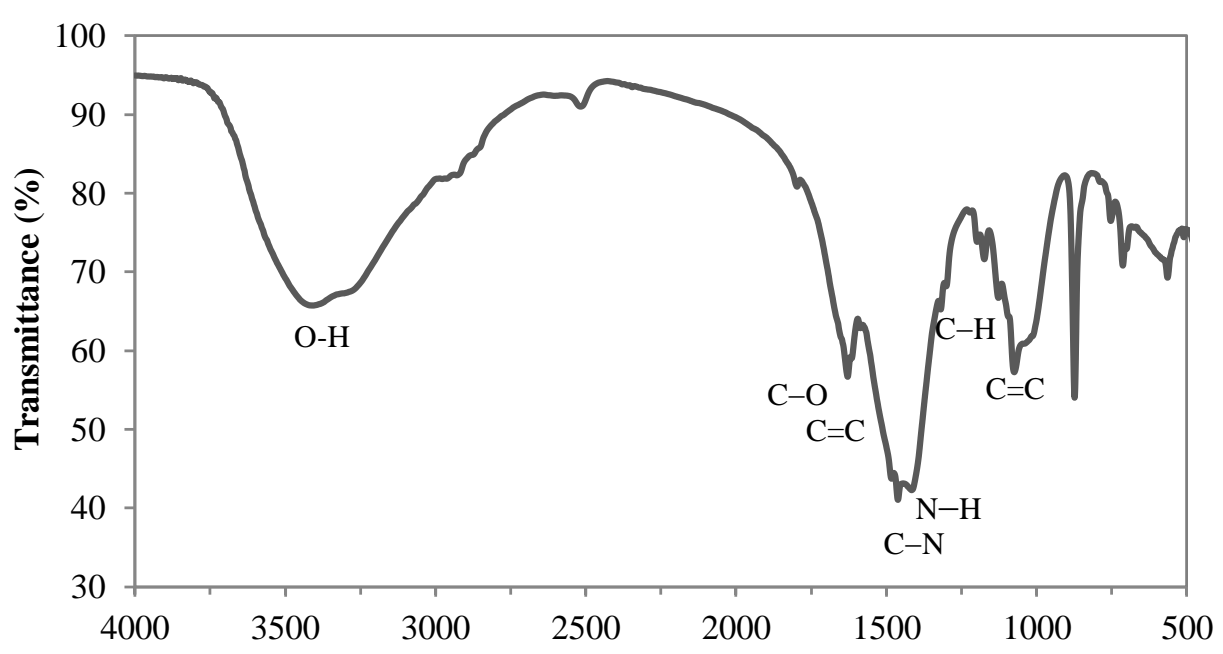

Wave Number $\left(\mathrm{cm}^{-1}\right)$

Figure 2. FTIR spectra of dye result of maceration method with neutral solvent

material storage temperature should be set not to exceed the room temperature. Ultrasonic wave aid seemed to help better extraction to release indican compounds from inside the leaves as well as twigs. As a result, the yield of the dye powder produced with the help of ultrasonic waves is relatively more than by using conventional immersion.

The condition or acidity of the solvent results in a different type of color. Blue color is produced under neutral (maceration and ultrasonication methods) and alcoholic solvent conditions (ultrasonication method). This acidity difference may affect the success of enzymatic hydrolysis and/or oxidation reactions to produce indigo compounds. It is reported that indigo can be reduced to leuco-indigo which is greenish-yellow in certain acidity conditions (Vuorema 2008).
Absorbance indicates the amount of light or energy absorbed by the particles in the solution and the absorbance is directly proportional to the concentration of the medium under test. Figure 1 shows the absorbance relationship of the indigo (blue) natural dye obtained from the maceration and ultrasonication method compared to indigosol, the synthetic blue fabric dye obtained in the market. Concentrations of natural and synthetic dyes were tested at a concentration of $1-5 \%(\mathrm{w} / \mathrm{v})$ and at a wavelength of $440 \mathrm{~nm}$. The dye obtained by maceration and solvent method under neutral conditions yields the highest absorbance compared to the dye obtained by ultrasonic assisted immersion. Compared with indigosol, indigo from neutral maceration is quite comparable, especially at concentrations of about $3 \% \quad(w / v)$. At 


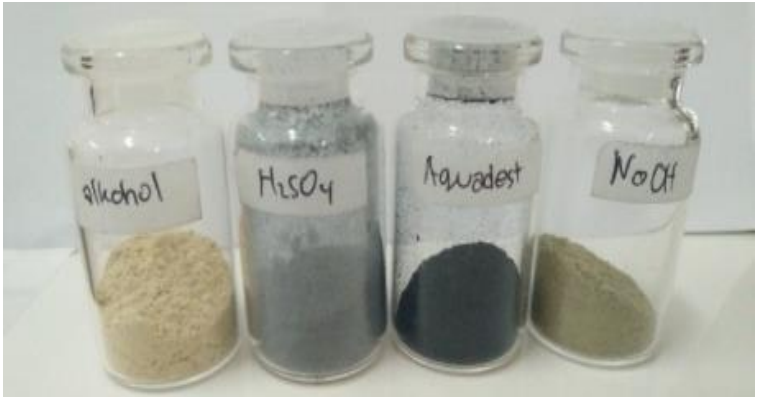

Figure 3. Indigo powder result of maceration method.

concentrations of less than $3 \%$, the absorbance of the natural indigo dye obtained by the method was higher than the synthetic indigo absorbance, and then above that the natural indigo absorbance was lower than the synthetic indigo. It has been reported that natural indigo also contains impurities such as indirubin, indigo-brown, indigo gluten and mineral matters (Perkin 1907). At low concentrations, the impurities may not interfere with absorbance, whereas at concentrations of higher than 3\% hindrance of absorbance may occur.

In the meantime, the absorbance value of the natural dye from the ultrasonication result shows almost the same value, despite showing lower values than the indigosol. The lack of linearity relationship among the natural indigo dye concentrations obtained by ultrasonication methods on alcoholic conditions of absorbance can not be explained with certainty. Ultrasonication may not only accelerate the indigo formation reaction but also accelerate the formation of other colorants that act as impurities. An advanced test of the dye content is required to know the components contained therein.

Figure 2 is an FTIR spectra of indigo dye produced from the maceration method using a water solvent under neutral conditions. The functional groups identified from the FTIR spectra are the $\mathrm{O}-\mathrm{H}$ groups at the $3400-2400 \mathrm{~cm}^{-1}$ wave numbers, aromatic plane of six $\mathrm{C}-\mathrm{H}$ rings on wave numbers 1608, 1463, 1061 and $870 \mathrm{~cm}^{-1}$, and vibration amine $\mathrm{N}-\mathrm{H}$ bond with vibration of $\mathrm{C}-\mathrm{N}$ simultaneously contribute to the wave number $1400-1417 \mathrm{~cm}^{-1}$. The $\mathrm{C}=\mathrm{O}$ group is detected at the wave number $1623 \mathrm{~cm}^{-1}$. The five-ring cyclical plane is identified at wave numbers 1299, 1293 and 870 $\mathrm{cm}^{-1}$.

Figures 3 and 4 represent the appearance of the dye resultant powder, either produced using traditional maceration methods or with the ultrasonication. The dark blue dye is produced by

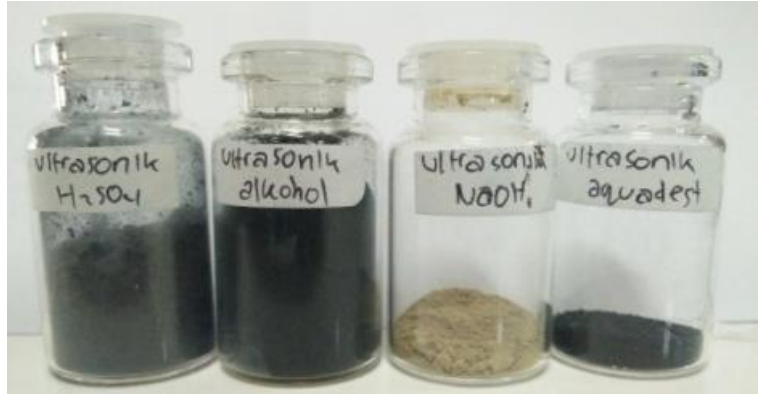

Figure 4. Indigo powder result of ultrasonication method.

using a coated maceration method under neutral conditions, and by using a coated ultrasonication method under neutral and alcoholic conditions. Further identification should be made to indentify other colours produced, such as grey, light brown and greenish brown.

\section{CONCLUSION}

Extraction of natural dye by using maceration and ultrasonication methods and difference of solvent condition have been carried out. The dark blue colour was obtained by using the maceration method with water solvent under neutral conditions and also by using ultrasonic wave aid as well as solvent under neutral and alcoholic conditions. Higher yields were generated using ultrasonication methods, eventhough it encouraged producing other dyes.

\section{REFERENCES}

Bechtold, T., Turcanua, A., Geissler, S., Ganglberger, E. 2002. Process balance and product quality in the production of natural indigo from Polygonum tinctorium Ait. applying low-technology methods. Bioresource Technology. 81(3):171-177.

Chanayath, N., Lhieochaiphant, S., Phutrakul, S. 2002. Pigment Extraction Techniques from the Leaves of Indigofera tinctoria Linn. and Baphicacanthus cusia Brem. and Chemical Structure Analysis of Their Major Components. CMU Journal, 1:149-160.

Maulana, I., Handayani, P.A. 2013. Pewarna Alami Batik Dari Kulit Soga Tingi (Ceriops Tagal) Dengan Metode Ekstraksi. Jurnal Bahan Alam Terbarukan. 1(2):1-8.

Mongkholrattanasit, R., Kryštůfek, J., Wiener, J. 2010. Dyeing and fastness properties of natural dyes extracted from eucalyptus 
leaves using padding techniques. Fibers and Polymers. 11(3):346-350.

Mualimin, A.A. 2013. Pewarna Alami Batik Dari Tanaman Nila ( Indigofera ) Dengan Metode Pengasaman. Undergraduate Thesis. Universitas Negeri Semarang. Semarang, Indonesia.

Perkin, A.G., Bloxam, W.P. 1907. Some constituents of natural indigo. Part I. Journal of the Chemical Society, Transactions. 91:279-288.

Punrattanasin, N., Nakpathom, M., Somboon, B., Narumol, N., Rungruangkitkrai, N.,
Mongkholrattanasit, R. 2013. Silk fabric dyeing with natural dye from mangrove bark (Rhizophora apiculata Blume) extract. Industrial Crops and Products. 49:122-129.

Tayade, P.B., Adivarekar, R. V. 2014. Extraction of Indigo dye from Couroupita guianensis and its application on cotton fabric. 2014:1-16.

Vuorema, A. 2008. Reduction and analysis Methods of Indigo. Turku, Finland. 